\title{
"What's New About Muslim Ismaili Transnationalism? Comparing Business Practices in British East Africa, Colonial Mozambique and Contemporary Angola"
}

\author{
Susana Trovão \\ New University of Lisbon, School of Social Sciences and Humanities \\ CRIA - Centre for Research in Anthropology
}

\section{Filomena Batoréu}

New University of Lisbon, School of Social Sciences and Humanities CRIA - Centre for Research in Anthropology

\begin{abstract}
The way in which the history of colonialisms might be link up with the formation of postcolonial migrant identities remains insufficiently examined. Through a comparison between transnational business practices of Khoja Ismaili Muslim settled in the British and Portuguese colonial territories of East Africa and in contemporary Angola, the present paper aims to discuss the impact of colonial experiences in the configuration of postcolonial business cultures. Articulating several guiding empirical questions, we will attempt to show that the continuing centrality of the nation-states in which Ismaili transnational economic activities are embedded, the notion of a disadvantageous network closure, concomitant with the importance of face-to-face contacts, the mutual trust and understanding sustained through personal relations, and the tendency for national loyalty to prevail over religious belonging (whenever any potential conflict between the two exists) constitute crucial dimensions of an accumulated colonial knowledge which is significant in the analysis of the Ismaili competitive advantage in postcolonial Africa. This argument will be developed on the basis of a multi-sited ethnographic research. The U.K. and Portugal emerged as a strategic passage for our encounters with East African Ismailis from former British and Portuguese colonial
\end{abstract}


territories. The current Angolan context, absent from the available literature, was selected as a postcolonial term of comparison.

Keywords: Ismaili transnationalism, trade and entrepreneurship, colonial and contemporary Africa

\section{Introduction}

The recent presence of a few hundred Khoja Ismaili Muslims - originating from Portugal, India, Canada, the Democratic Republic of the Congo, South Africa, Kenya, Uganda and Tanzania - in the current Angolan context ${ }^{1}$ is both enigmatic and largely invisible $^{2}$. Although strategies of invisibility were observed in many trading entrepreneurs and the recent history of Ismaili displacement has been closely connected to African territories (Penrard, 1988; Salvadori, 1989; Kaiser, 1996; Daftary, 2000), their presence in Angola is unprecedented.

The forefathers of these entrepreneurs migrated from Gujarat and settled in the British colonies and protectorates of East Africa, South Africa, and the Portuguese colony of Mozambique during the second half of the nineteenth century. Under Aga Khan III's guidance from 1893 onwards and continued through the twenty century a new ethics ${ }^{3}$ became a religious duty within African Ismaili communities. Aga Khan III

\footnotetext{
${ }^{1}$ Our data point to the existence in Angola of approximately six hundred Ismailis, half of which originate from Portugal; approximately two hundred and fifty from India, while the rest hold other nationalities. Processes of family reunification have recently begun, and our data recorded 430 adult males, 100 adult women, and 70 children.

2 Although they recognize the contribution of Ismaili entrepreneurs (with whom they have been cooperating since the late 1980s) to national development, Angolan political elites tend to gloss over the religion of their business partners. Confronted with the unprecedented and growing presence of a Muslim population (both immigrants and converts), the Angolan State persists in refusing to make Islam legal.

${ }^{3}$ Two main doctrines - ta'lim (followers render unquestioned allegiance to a infallible Iman) and ta'wil (the possession by the Iman of esoteric competences and knowledge which empowers him to interpret holy laws and sacred texts in according to historical changes in the external world) contributed to its fairly rapid acceptance by African Ismailis.
} 
gave farmans to his followers to practice a inner-wordly asceticism which made hard work, rational adjustment and success in material affairs meritorious attitudes and a major virtue in the eyes of God. Articulating economic prosperity with social and spiritual welfare, this new ethic aimed at modernising Khoja Ismaili whose cultural baggage was of a rural origin. The intercontinental business networks together with the multiple colonial social capitals they had accumulated in colonial African territories enabled them to construct and increase their status as a mercantile group.

After the independence of African states, in the late 1960s and 1970s, those who had settled in Kenya, Uganda and Tanzania migrated primarily to Canada and the United Kingdom. A few years before the Portuguese democratic revolution of 1974 and the decolonization process, Ismailis also relocated from Mozambique to Portugal. Despite the economic opportunities offered by many E.U. countries following the integration of Portugal into the European Economic Community in 1986, some of them decided to take a chance in Angola. From 1989 until now, their investment in the country has steadily grown and diversified; since 1996, they have also acted as the local "hosts" to a considerable number of Canadian transnational entrepreneurs from the same religious community, most of whom born in British East Africa, who were looking for new investment opportunities.

A number of research trends have already begun to trace the contours of a postcolonial approach, focusing on the cultural effects of different colonialisms and colonial experiences in the power dynamics of post-colonial societies, as well as on the legacies of colonialism in the construction of transnational relations between former colonies and their colonizers. However, the way in which the history of colonialisms might be link up with the formation of postcolonial migrant identities, although posited as crucial, remains insufficiently examined. Comparing the business practices of Ismailis 
settled in the British and Portuguese colonial territories of East Africa and in contemporary Angola, this paper aims to interrogate the impact of Ismaili colonial experiences - within and between different colonialisms - in the configuration of a postcolonial transnational business culture. Concomitantly, the analysis of the continuities and discontinuities between business colonial past and postcolonial present in Angola will enable to discuss several conceptual antinomies fuelling much current debate on postcolonial diasporas.

What is (or is not) transformative in the management, organizational and business practices historically constructed by Ismaili entrepreneurs in colonial and postcolonial African contexts? Despite recognising that transnationalism is not a new phenomenon, a significant percentage of available literature still emphasises the peculiarity of recent experiences. Developments in transportation and communication technologies, new international forms of economic activity and the changing nature of the labour markets (among other dimensions) are frequently revisited to validate fractures between past and present transnationalisms (Appadurai, 1996; Foner, 2000; Levitt, 2001; Inda \& Rosaldo, 2002; Smith, 2003; Vertovec, 2009). However, several other scholars believe global contemporaneity cannot yet be conceived as an experience of rupture (Miller, 1995) from the preceding contexts; nor can it be defined as a new "integrated global order" (Vertovec, 2009: 2), responsible for the production of original transnational social formations. The contribution of the present case study to the "what's old/new" debate consists in demonstrating how a combination of modes of transnationalism and integration in different colonial African territories made it possible to develop "tacit knowledge" (Amin \& Cohendet, 1999), which has more significance than today's modes of transportation and real-time communication for the analysis of the successful integration of Ismaili entrepreneurs in postcolonial African contexts. 
To which extent have these entrepreneurs articulated opportunities derived from economic globalization processes with the specific (historical, socio-political, cultural, etc.) dimensions of the structural and relational contexts in which their transnational businesses were embedded? While refusing to remove both the "present" and the "past" from their historical contexts, the comparative analysis of Ismaili entrepreneurship will mobilise different facets of its embeddedness (Granovetter, 1985; Portes, 1995; Yeung, 2000; Dicken et al 2001): linkages to international and global levels of economy and polity (through support and advice structures provided by Imams); lateral connections between diasporics settled in different countries (including expectations, reciprocity, etc.); and the connections between partners directly and indirectly involved in the economic transactions carried out in specific socio-historical contexts.

Have Ismaili entrepreneurs combined transnational investments with local integration? A significant body of empirical research has clearly demonstrated that transnationally connected social actors are able to develop significant processes of integration (Tololyan, 2000; Levitt, 2001; Portes et al 2002; Joppke \& Morawska, 2003; Smith, 2006). Although numerous scholars argue that the understanding of transnationalization and integration is enhanced when they are analysed as inextricably intertwined social processes, they nonetheless tend to highlight alternatively the coexistence or competition between these two components in the life of many migrants (Vertovec, 2009: 81). Our findings, however, call for further work on "the multiplier effects" (Guarnizo, 2003) generated between transnational and local economic activities.

How can the obligations of intra-community solidarity (both local and transnational), associated to a certain degree of ethno-religious closure, be concomitant with the appreciation of individual initiative from which internal competitiveness 
originates, and with the orientation to interact with other people and spaces? We will argue that these apparent "dualities" (Penrad, 1988), with which the Ismaili entrepreneur is very familiar, are part of the tacit knowledge developed through multiple historical negotiations. Community cohesion and competition between peers (including within a single kinship network) are understood as indispensable factors for economic success. Personal relationships with elements pertaining to the different social strata (from the base to the top) present in the various settlement societies, and the parallel development of skills in manoeuvring particular systems of values, meanings and practices are a critical factor in gaining competitive advantage.

Why does belonging to a transnational religious "imagined community" not clash with the development of national identifications and/or with loyalties to colonial and postcolonial nation-states of settlement? The present paper, while only in exploratory form, will serve to underline the significance of dialectic processes of remaking colonial and post-colonial experiences of transnationalism and integration in order to understand the identity alignments and strategies mobilized by Ismaili entrepreneurs moving back to Africa.

The research design entails a strategic comparison involving the construction and reinterpretation of historical and ethnographic accounts that take boundedness for granted so that transnationalization and reterritorialization processes - and their articulation - may be highlighted. At the same time, processes of transnationalism and local integration promoted by Ismaili entrepreneurs who settled in British and Portuguese territories of East Africa during the colonial period will be compared with equivalent processes, developed by a number of these entrepreneurs in the postcolonial African context. Previous research has focused on the return of a number of them to Kenya (Kassam-Remtulla 1999) or Mozambique, such as our previous work (Bastos 
2005); that is, former colonial territories in which their presence had been strong. The absence of previous colonial connections to Angola, and the coexistence in the territory of a significant number of major entrepreneurs of Portuguese and Canadian nationality (who have been mobilizing their family and community networks, in Portugal and India respectively, to recruit trustworthy employees), led us to select the current Angolan context as a valid postcolonial term of comparison in our research.

In order to operationalize the comparison, we developed a multi-sited methodological strategy. We held a total of 37 in-depth interviews with male informants who defined themselves as transnational entrepreneurs. Ismaili communities in the UK and Portugal emerged as a strategic passage for the encounters with East African Ismailis from Tanganyika, Zanzibar, Kenya, Uganda and Mozambique. To reconstruct and compare colonial experiences we selected several members (mainly second or third generation African born Ismailis, aged 65-85 years) of fifteen transnational family companies based in Zanzibar, Pemba, Nairobi, Kampala, Dar-esSalam, Kisumu, Nampula, Beira and Lourenço Marques which main business lay in trading operations trade and commerce. In Angola, we collect the migratory and business life history of thirteen Ismaili transnational entrepreneurs (nine of Portuguese origin and four born in British East Africa) whose ages ranged between 45 and 72 years. Settled in the country between 1989 and 2006, their companies were operating in very diverse economic sectors (hospitality and tourism; supply and distribution of food products, construction works and building materials, agro-industry, pharmaceuticals and equipment hospitals, telecommunications, furniture and design, etc.) having branches in Portugal, Brazil and Mozambique (when led by Portuguese) or in Canada, India, Uganda, Kenya and Congo-Kinshasa (in the case of the Canadians from East Africa). Conducted individually, these interviews were focused on migratory trajectories 
and transnational business activities (organization, networks, markets, operations, strategies, competitors, circulation, information, interethnic and interpersonal relationships). Class values, family dynamics, specificities associated to a shared ethnoreligious affiliation, new strategies and resources developed over decades of relationships with other groups in different colonial and postcolonial societies were also taken into account. In addition to these interviews, five biographies of women who lived in the colonial territories under study together with some interviews to three interlocutors who move regularly between Angola, Canada and Portugal will serve to underline the decisive role played by wives-mothers in continuing their families's economic enterprises.

\section{Transnational connections and colonial involvements in East Africa: Patterns of Business Organization}

As an example of direct connection between the local and the global, unmediated by the British colonial administration, a number of trading networks of Gujarati origin had a significant role in India's foreign economy in the first half of the $19^{\text {th }}$ century. Among them, several Khoja Ismaili Muslim ${ }^{4}$ merchants used the dominant role they played in the trade and finance of the Omani State to extend their activities along the East African coast (Markovit, 2001; Clarence-Smith, 1989). They engaged in trade along the coastline, import-export to and from India, tax collection, and some of them also financed the trans-Atlantic slave trade. In the late 1800 s, on the advice of their religious

\footnotetext{
${ }^{4}$ There is some evidence that it was Pir Sadardin (Sadr-al-Din) who converted many Hindu merchants of the Lohana caste (from Sindh and Gujarat) to Nizari Ismailism in the $14^{\text {th }}$ century. By the $19^{\text {th }}$ century, Indian Ismailis (also known as the 'Khoja') became one of the most powerful trading communities of East Africa. It is generally accepted that their expansion and success has been the result of enterprising investment within an organized diasporic community, guided by a "present and living” Imam.
} 
leader Aga Khan III, a significant flow of Ismailis left the regions of Kutch, Sindh, Katiawar and Gujarat in Northwest India (Kanji, 1990; Asani, 1994) in search of better socio-economic opportunities.

Among the pioneers was Alidina Visram Lalji, born in the village of Quetta (in Kutch), who moved to Africa at the tender age of 12 and worked for other Indian traders in Bagamoyo (on the coast of the Indian Ocean, close to the island of Zanzibar). Building upon the expertise acquired as an apprentice, he established his own business network, opening and supplying numerous outlets inland, where he bartered imported goods for ivory and pelts. Around 1909, his commercial empire already included over 40 branches all over East Africa, as well as several factories (Penrard, 1988; Salvadori, 1989). The numerous innovations he introduced - the increased volume of exchanges and the greater stimulus to the supply of new local products, their transformation into exportable goods, the transnational organization of his business (with branches in India, Uganda, Kenya, Tanganyika, Zanzibar, Congo and Sudan), and the investment in banking activities (Penrard, 1988) - were rapidly adopted by other Ismaili businessmen. Such were the cases of Pradhan Babool, Noormahomed Rawjee, Mahomed Bhanjee, Gulamhusem Jina, or Hazur Mukhi Tharani, still remembered as the most preeminent importers/exporters, who brought great prosperity to Mozambique. Mainly established in the North of the territory, they also diversified and enlarged import/export circuits with branches all over the colony and in other non-Portuguese African territories. The family histories recorded enable us to synthetize their patterns of circulation and business organization.

A pre-existing business culture, associated to some experience in long-distance import/export activities, developed from a number of small- and medium-scale locations (both coastal and inland) in Gujarat, provided motivation and essential resources to the 
pioneers. For those who did not have such background, the decision to migrate was influenced by belonging to the same religious community as those already established, who in turn offered employment abroad, initiation in the business culture, and, in certain cases, support to entrepreneurial autonomy.

The import/export business was made possible by the implementation of transnational connections and exchanges (of goods, people, capital, etc.) which firstly included India, the nuclei of co-ethnics settled in East and Southern Africa, and other more profitable regions (e.g. Singapore, China, Japan, England, Portugal, etc.).

"My dada [father's father] began by opening a rural trading post, then a second one, until he became a wholesale, also importing and exporting African products. He always worked with his brothers. The business belonged to the five of them. Usually, two or three brothers went to Africa; two others stayed in India to manage other firms and take care of the parents. They interchanged goods." (J., born in Kenya, lives in the UK)

"My great-uncles were importers. They imported mainly from India, Japan, China, England, and Portugal. They also exported to various countries, to India and Kenya too. (...). My father's sister married into a family from Mombasa, and they worked as middlemen for our exports to Kenya. (...) We also were money exchangers." (T., born in Mozambique, lives in Portugal)

The migratory experience of a family member frequently called upon brothers and cousins to also try their fortunes in the same or different African territories. Movements of family dispersion (to increase opportunities and/or to overcome legislative obstacles to migration in certain territories), partial family reunification (especially when one male set up a business and then recruited his brothers and cousins), and family refragmentation (in order to increase the branch offices of a business) made the import/export business possible, while keeping it under the control of trustworthy 
family members. The mobilization of affinal relations (established by aunts, sisters and daughters scattered in other African colonies) also gave dynamism to connections "here" and "there".

The establishment of long-distance enterprises was closely articulated with the construction of regional and inter-regional chains, consisting of one or more import/export firms and warehouses in urban areas to guarantee the regular supply of imported goods to multiple rural trading posts, which in turn were expected to supply produce for export to the urban warehouses. The maintenance of interdependence relations between wholesalers/importers/exporters and local merchants, and between the latter and the local population was vital to the fulfilment of business objectives. The construction of regional and inter-regional chains required the recruitment and deployment of trustworthy employees, chosen within the family network as well as among friends or members of a different community of Indian origin with commercial expertise and local contacts with the African population.

Managing the family's economic enterprises required blending an indispensable dose of economic rationality with several relational strategies among the relatives involved: partners with the same or different shares in the company, who did or did not derive the same profit, differentiated in the micro-family hierarchy, as well as in their performance, degree of autonomy and entrepreneurial pre-eminence. The potential vulnerability of this entrepreneurial pattern emerged precisely on the occasion of the death of one of the founding members, who had to give "final consent" to any business decision. This situation, associated to the intergenerational multiplication of partners, frequently resulted in the dissolution of these partnerships, and in the establishment of new businesses in which a father and his sons would begin once more to "work together in the family business". A second potential risk was connected to the recruitment of 
employees. The preference for kin and/or community members was bound up with a question of mutual trust. The barter business was difficult to control at a distance, and frequently involved no written records. It was highly dependent on trust between partners, and frequently involved employees who did not have a contract with the firm. However, when the business reached a significant level of growth, diversification and transnationalism, other criteria (such as skills) became progressively more important.

Business was something to be taken care of by men. Mothering, family relations and culture/religion constituted the fundamental "work" of women. However, female attempts to not contaminate the masculine relations of consanguinity with the typical family conflicts (between mothers- and daughters-in-law, or sisters-in-law), the strategies they used preparing their offspring to give continuity to the family business (transmitting them the entrepreneurial action of previous generations and instilling values of effort, work and sacrifice), or the manner in which some mothers (mostly educated in Kenya) started to stimulate the academic and professional training of emerging generations were crucial in the consolidation of the family business model.

\footnotetext{
"Our mothers had a very good philosophy. If there was any problem among women, they tried to solve it and said nothing to their husbands. The idea was always to avoid resentments, because family unity was very important in the family business. Even though they did not take the active part, their main task was to prepare sons to continue the business their fathers had developed." (Nu.., born in Kenya, lives in the UK)
}

The role of married women as transnational family managers also configured an important business resource. Not infrequently their relations with relatives settled in the same or different territory were capitalized by their family of alliance (and vice versa) to guarantee loans or direct banking, commercial licenses, and the confidence of suppliers and customers, to exchange information and advice on investment opportunities, or to 
expand the transnational organization of the business. In all these procedures, feminine diplomacy was essential for any of their male relatives felt "humiliated". Managers of family relationships that indirectly interfered with the business of their families, women contributed to an economic project within which subject, family and business overlap. While keeping watch for the "respect"/"reputation" attached to the family's name, they also worked to maintain an indispensable ingredient in commercial transactions based on mutual trust.

Since the commercial sector had diversified both in British and Portuguese colonies of East Africa and offered more scope for expansion, the major economic interest of the Ismaili firms lay in international trading operations and commerce. However, from 1930's onwards there was a gradual diversification of the family businesses when some Ismailis became flour and oil milliers, soap manufacturers, sisal and cotton planters or road hauliers. In parallel, a number of entrepreneurs also began to invest in the industrial sector (i.e. textiles, mining, construction and materials). The family-based shareholding structure was maintained (albeit with changes to fully exploit new opportunities); however, the establishment of industrial projects closely associated to local development ${ }^{5}$ translated into stronger economic and interpersonal relations with non-Ismailis ${ }^{6}$.

\footnotetext{
${ }^{5}$ Portuguese colonial authorities in Mozambique barred access to industry to minorities of Indian origin, and a "Portuguese partner" became therefore indispensable. In East Africa, the aim of organizations such as Promotion Services (established in Nairobi in 1963) was precisely the promotion of industrial enterprises (making it easier to access the required capital), in particular those involving Ismaili and nonIsmaili partners.

${ }^{6}$ After the Second World War, advised by their Imam, Ismailis also started to invest in the university education of the youngest generations, thus laying the foundations for a diversification of professional opportunities (medicine, dentistry, law, accountancy and so on). During the 1950's, several girls began attending secondary school education (in Ismaili schools which had been co-educational). Progressively, some of them had also benefited from higher education and training for certain professions. Before decolonization, women have been able to participate actively in their family enterprises. However, since the
} 
Becoming a transnational trader, a settled wholesaler, importer/exporter, engaged in banking activities and/or an entrepreneur, required, as we will see further on, an identification with the historical projects of British and Portuguese colonizers, as well as recognition on the part of the governing classes that these entrepreneurs were political and economic partners indispensable to the development of the colonial territories themselves. Business organization therefore depended on the close articulation of the colonial logic with strategies of globalization of capital and exchange, and of the latter with family and community resources.

\section{Reacting to Colonial hostility: Patterns of Circulation and Reterritorialization}

Ismailis were legally recognized as British subjects after 1843, as were all residents of British India. They were entitled to the protection of the British Crown in 1858 (Morris, 1969; Gregory, 1993). As such, they were entitled to travel and reside in the territories under British rule as well as in the foreign territories which maintained diplomatic relations with Britain (as long as they were recorded with local British consulates).

Limits began to be imposed in 1890, when the Boer Republics and the colony of Natal began to adopt restrictive measures against Indian immigrants. Based on racial prejudice and ideological religious considerations, anti-Indian feelings experienced a steady growth and expansion to other East African territories, especially Kenya.

1960's, the major investment of Ismaili wifes/mothers became the academic education of their children. As explained by our interviewees, this was due to a directive upon which Aga Khans had much insisted: "If a family can only afford to educate one child, then it must be the girl, because she is the one who will be a mother and mothers are responsible for the education of their children. An ignorant mother cannot help her children, or she will find it harder. Investing in the education of girls means investing in the education of the whole following generation." (Ny..., born in Mozambique, lives in Portugal) 
Mozambique thus became a new Eldorado. In fact, a significant number of the family histories of those who arrived in Mozambique after 1911 reveal that the increased hostility of European-origin colonists to the presence of Indians in South Africa and Kenya, and the restrictions to their entry into these territories, as well as the existence of support networks implemented by the pioneers, turned this Portuguese colony into an appealing alternative destination.

"My grandfather hosted many Ismailis who arrived with the idea of settling in South Africa. Back then, at the turn of the century, it was an Eldorado, everybody went looking for gold. It wasn't extraordinary for 40 to 50 people to have lunch in my dada's house. Things became more difficult however, and many Ismailis decided to stay in Mozambique." (I., born in Mozambique, has been living in Portugal and the UK)

In 1932, however, the Government of Mozambique also issued regulations limiting the entry, circulation and employment of Indo-British immigrants in the colony, despite repeated protestations on the part of the United Kingdom. The powerful Nationalist movement which had begun in India led British authorities to reconsider the situation of Indians in South Africa, beginning in 1919, and in Kenya, Zanzibar and Mozambique after 1920.

In an era in which free travel was coming to its end, Ismailis began to modify their circulation practices. The pattern of male migration was progressively abandoned. The local presence of heirs to give continuity to the family business became paramount, persuading most of them to start processes of family reunification and reterritorialization. In parallel, the measures implemented by Aga Khan III to encourage their de-Indianization and Westernization, which included incentives to complete family reunification outside India, and the disapproval of the "one foot here, one foot there" attitude, contributed to increase their identity involvement with colonial African 
territories.

The encounter with colonial and racial systems in East and South Africa associated with multiple legal obstacles to business, employment and circulation pushed Ismailis toward a sustained transnationalism between concentrated and segmented communities which were integrated in different settlement societies. Once again the Ismaili African past demonstrates that processes of reterritorialization do not constitute a countervailing tendency to transnationalism.

\section{The Politics of Ismaili Businessmen}

Un des principes de notre religion est d'être loyal et fidèle au gouvernement qui assure sécurité et justice (Aga Khan III).

Although Ismailis did not take interest in politics, local and international trading networks forced them to fit in with the colonial systems in the geographies they were present in. Due to the systematic efforts of their "living" Imam, they organized themselves so as to become political agents, active and cooperating with the authorities of their respective colonial societies.

Aga Khan III was committed to overcome the stereotype of the opportunistic and instrumental Indian migrant, faithful to his origins, enclosed in his religious community, with no feelings of identification, loyalty, or gratitude towards his host society. In 1914, during his second visit to Burma, he advised his followers to give up their Indo-Muslim names and habits, in order to facilitate their socio-cultural assimilation (Daftary, 1990). In later years, he often recommended similar measures to his followers in several parts of British East Africa (Salvadori, 1989; Sumra, 1990; Walji 1980; Kaiser, 1996): "Burn the bridges - we don't want one foot in India and the other in Kenya." (KassamRemtulla, 1999). Addressing a farman to all Indians settled on "Portuguese (African) 
soil", he also restated - "You must be Portuguese first, and only then Indian" (Bastos, 2008). As well as stimulating feelings of national belonging, some of the actual reforms he promoted - especially those related to gender issues, strongly associated to notions of "modernity" and "progress" - also aimed to show Ismaili acceptance of supposedly European values. He was indeed quite successful in persuading the British and Portuguese colonial governments to recognize the uniqueness of the Ismaili communities as "close" political and civilizational "co-operators" (Bastos, 2008).

The post-War period saw the independence of India, Partition, and a gradual deterioration of the relations between Portugal and the Indian Union, culminating with the invasion of Portuguese India in 1961. The then Governor General of Mozambique determined the "internment" of Hindustani citizens, a prohibition on issuing them with any entry or exit visas, and "the closure of their commercial enterprises and private residences". The Ismailis, in their majority not naturalised as Portuguese (despite their insistent desire to do so, in particular after Partition), were protected by the amicable relationship between their leader, Aga Khan, and the Portuguese government.

"In ' 61 , the government decided to seize all our assets, all property was still in the name of our grandfather and his brothers. Some had British documents, other descendants had become Pakistanis after Partition. We had been born in Mozambique. We had to hire a lawyer to make the required applications and explain the situation. (...) With the influence of His Highness Aga Khan, most Ismailis managed to avoid the public auction of their assets." (K., born in Mozambique, has been living in Portugal, Canada and Angola)

The structural ambivalence of colonial authorities towards Indians, granting them protection when they had political, economic and social advantages to offer in exchange, while using them as scapegoats in times of crisis and nationalistic 
exacerbation, underscored the importance of transnational connections. Thus many family businesses continued to increase their transnational economic practices with investments in India and Pakistan, neighbouring African territories and Europe with the aid of family members and co-ethnics who provided information on the best business opportunities and acted as middlemen, partners or local foreign managers. On the one hand, transnationalism offered protection (against increased racial tension, unfavourable political conjunctures, etc.); on the other, it was always risky, especially in the context of independence and Africanization processes.

"In 1963, Tanzania became independent. And, since Julius Nyerere was a stable leader, we thought it was good to invest in an independent country, still without much competition, we bought apartments and factories in Tanzania. We bought them for a good price, and thought we could make a profit. And shortly after we bought, nationalization began. We lost everything. Later, we lost even more in Kenya." (Z., born in Kenya, lives in the UK)

\section{Secrets of the business: Circulating Information and Knowledge}

A vital element in the import/export business, the circulation of information required i) the conjugation of strategies of inter-ethnic openness and trust, with ones of intercommunity closure, both indispensable to local and long-distance commercial transactions; ii) the existence of selective mechanisms of secrecy, both within and outside family and community networks; iii) as well as the subordination of all these tactics to knowledge produced and disseminated by the Ismaili institutional hierarchy.

During the many centuries of their African past history, the processes of dissemination of information on import/export opportunities, markets, products and prices, the business reputation of potential partners, as well as factors to temporarily help or hinder the circulation of goods, people, and capital, were remarkably similar to 
those through which the news of births, deaths, marriages, family or community disagreements were spread among nuclei so often separated by great distances.

Since the early $19^{\text {th }}$ century, and at least until the mid- $20^{\text {th }}$, a significant majority of Ismailis settled in Africa were temporary migrants. While family reunion was fairly common, many still returned periodically to their place of origin, then back to Africa after a few months. During both trips, they took advantage of the stopovers of their ships, along the East African coast to visit relatives and fellow countrymen, actively contributing to the exchange of information and business knowledge. At the same time, the significant increase in marriages among African-born couples encouraged the circulation of people and goods, as well as creating new opportunities for the circulation of information, complemented with letters and telegrams (in the Gujarati or Kutchi languages).

Weddings, ceremonies on the religious calendar, and the periodical visits of the Imam to the Ismaili communities settled in Uganda, Kenya, Tanzania, Mozambique or South Africa all offered opportunities for the spatial re-concentration of wide-ranging and scattered family and co-ethnic networks and therefore for the exchange of varied knowledge and information. On the other hand, regular meetings between the leaders of Ismaili organizations (Supreme Council for Africa, Territorial Councils, Provincial Councils, etc.) offered access to information on the global scale (through the international support and consultancy structures of the Imam), subsequently transmitted to multi-localized networks of businessmen.

The intra- and inter-community circulation of information - inseparable from the values of solidarity and mutual help strengthened by the personal experience of religion - did not, however, happen transparently and uniformly. Strong competitive and mimetic dynamics among the Ismaili required the development of mechanisms to 
selectively filter and conceal information between rival networks and partners.

A business culture which knew precisely how to circulate capital, people, goods, information and knowledge, whose mechanisms of transmission were selective and secret, and subordinated to a hierarchical community structure became a differential factor for comparative success. It was also decisive in planning and implementing the decision to quit African colonial territories in the 1960s and 70s.

"After the crisis in Uganda and when the military situation in Mozambique worsened, the Aga Khan met the leader of the Mozambican community to prepare our departure toward Lisbon. One or two members of each family were contacted, all across the territory, by a number of individuals held in great trust by the whole community. They explained to us what we had to do to sell our property, exchange money or transfer our holdings without arising any suspicion, and how several thousands of people would be transported without anyone questioning it all - not the government, not local administrators, not the DGS. This was a secret that no one could disclose. My best friend, a Hindu, never forgave me.” (I., born in Mozambique, has been living in Portugal and Angola)

The memories of the "departure" from Mozambique of the whole Ismaili community between December 1972 and mid-1974 (that is, before the democratic revolution in Portugal and subsequent decolonization) clearly show that the patterns of circulation and the same idea of secrecy used in business dealings could, following an order of their leader, spread throughout the community and therefore make it possible to carry out a complex and politically tricky operation, whose success depended on closely guarded secrets.

\section{Family transnationalism: old business strategies for postcolonial crises}


Ismailis had scarce contact with the Asian associations that, merging their political interests with those of the Africans, opposed many forms of economic, political, social and racial inequality in the East African colonial system ${ }^{7}$. Moreover, before the independence processes, they frequently assumed a neutral "wait and see" posture in the conflicts between Africans and Portuguese or British colonizers. As several community leaders pointed out, their communities never did carry out any serious debate about independence and its consequences in order to form a concerted approach.

According to some of them, the Ismaili "refusal to get mixed up in politics" was the result of the Aga Khan's general policy of concentrating on economic development as opposed to politics; others mentioned that Aga Khan believed that Ismailis' future was best secured by the perpetuation of the British rule and the Portuguese regime; still others said that it was the product of the higher investment (passed down through the generations) in religious communities and family businesses which "alienated Ismailis from what goes on around them and the World". Exceptional, political activism provoked not only opposition from local Ismaili communities but also from the Imam who wanted his followers to dissociate from any co-operation with African (and Asian) nationalists.

Although their influential business in Tanganyika, Kenya and Uganda, what cannot certainly be denied is that the de-colonization processes inflicted times of great socio-economic and identity insecurity upon East African Ismailis, and conditioned their subsequent migratory patterns and routes. Among the memories which still mobilise the strongest emotions are those linked to anti-Indian discrimination and the diaspora of terror during the Africanization processes.

\footnotetext{
${ }^{7}$ Identifications with Portuguese and British colonizers were not, however, incompatible with indirect forms of opposition to discriminatory measures and practices affecting non-white communities.
} 
"Ismailis felt comfortable and protected during British rule. There were no conflicts between whites, Indians, and Africans. Those only began after independence. Indians had always helped whites, so Africans though we were on their side. On the other hand, whites began to say that Indians were to blame, we were the exploiters, we only wanted to earn money and send it abroad." (J., born in Uganda, lives in the UK)

The majority of Ismailis migrated to postcolonial U.K. (in three waves from 196465 onwards, the latter after their expulsion from Uganda in 1972) and Portugal (between 1972 and mid-1974). They held Portuguese or British citizenship and passports from their respective colonizing powers. A significant number of them also moved to Canada (since the Aga Khan IV was able to obtain quick naturalization for his followers in that country), fewer migrated to the United States, and fewer still to South Asia. The caution and discretion with which some of them sold their assets and transferred their capital outside Africa as well as the international political and economic contacts of their leadership enabled them to maintain their generally ascending migratory histories. These however were not the only grounds for their postcolonial success.

While this may appear surprising, their more recent strategies of circulation and business organization were very similar to the ones deployed by their grandfathers and great-uncles in Africa in the late $19^{\text {th }}$ century. Among them, the dissemination of the extended family in various countries, the establishment of import-export firms in each new host country, a regular exchange of goods and capital, family management, the mobility of certain family members (to make import/export processes easier), the gradual diversification of business areas, and the quest for new opportunities in different countries (based upon the information of economic consultants belonging to the transnational Ismaili organization). In addition, philanthropic investment in areas considered disadvantaged or politically desirable by the new host countries also helped. We would agree with Morawska, "that life worlds and diaspora politics of turn-of-he 
century immigrants share many of the supposedly novel features of present day transnationalism" (2001: 178).

"In 1973, my mother and father and some of my younger brothers went to Portugal, while my wife and I and our five sons went to Pakistan; other close family members went to Canada, still others to the UK. After two years in Pakistan, we went to Canada. I set up an import/export business, with connections to South Africa and Portugal. Two of my brothers were in Pretoria, I was in Toronto, my father in Portugal, with my youngest brother. This is how the family business continued. Between 1976 and 1981, we also began to invest in Swaziland, in construction, ground levelling, and road building, then we bought the concession for a coalmine. In the early $1990 \mathrm{~s}, \mathrm{I}$ heard that you could do good business in Mozambique and in Angola." (Za., born in Mozambique, has lived in Pakistan, South Africa, Canada, Swaziland, Mozambique, and Angola)

\section{Moving back to Africa ${ }^{8} .$, What's New about IsmailiTransnationalism?}

The independence of Angola (1975), closely connected to the Portuguese revolution of 1974 and the subsequent process of decolonization, happened in the international framework of the Cold War. The new country, led by the MPLA movement, joined the Soviet bloc. The political experiment of the First Republic, inspired by the MarxistLeninist ideology (which became official in 1976), did not successfully implement a system of central planning and State monopoly of external trade. It also revealed its contradictions in the management of the oil sector, which despite being controlled by the leaders of the Single Party/State, was heavily dependent on foreign companies and oriented towards the international market (Aguilar, 2006).

According to available studies (Bhagavan, 1986; Hodges, 2001, 2003; Aguilar, 2006; Vidal 2007), such centralized management actually resulted in countless business

\footnotetext{
${ }^{8}$ Since the mid-1990s, Aga Khan IV has encouraged African Ismailis in the West to reinvest in Africa, move back to their places of birth, or explore opportunities in several other African territories.
} 
opportunities. The collapse of production ${ }^{9}$ which marked the end of the 1970 s and the early 1980s (affecting agriculture and fisheries, as well as mining and manufacturing) forced a marked increase in the import of all kinds of goods, controlled by political elites and financed by the profits of the oil industry. This scarcity of goods also resulted in large, thriving, and diversified black and gray markets, and to the subsequent great imbalances between official and black market prices, which encouraged all kinds of lucrative "schemes". A drawn-out war, destructive to most of the scarce national production (as well as to most infrastructures, especially outside the capital, Luanda) increased the need for imports and promised rapid profit to potential importers. These three interconnected aspects translated into a unique opportunity for several Portuguese Ismaili (family-owned) businesses which specialized in international trading (importexport) and became heavily involved in the Angolan market in the mid-1980s.

"We spoke Portuguese, had the entrepreneurial know-how and a previous connection to Africa through Mozambique. We were in a privileged position. We saw Angola as a natural return to Africa. Other than the Cubans and Russians, we were among the first to gain entry." (F., born in Mozambique, has been living in Angola since 1987)

"A. was the first firm to submit a bid, and from then on won all public tenders, everybody knew A. would win. On the one hand, because it had the lowest prices, and on the other, because we gradually strengthened our relationship with influential people in Angola. After all, the country needed everything. And we had experience in international trade. Around 1988/89, during the war in Angola, that's when our business grew" (N., born in Mozambique, president of the A. group with head offices in Lisbon and major branches in Luanda, Cabinda, Johannesburg, Madrid, Milan, and New York)

\footnotetext{
${ }^{9}$ Made even more pronounced by war and the departure of over $95 \%$ of the 340,000 Portuguese settlers who managed businesses and farms (Bhagavan 1986).
} 
The economic experiences of the Socialist era cannot be dissociated from a set of phenomena identified as Neopatrimonialism in the available literature on Africa (Ellis \& Fauré, 1995). The recognition that access to the State and to the higher ranks of the Party represented an economic resource, and - equally significant - the required adaptation to the strong personalization and patronage-based nature of business relations determined the success of the pioneering Ismaili businessmen.

"In Angola, business would grind to a standstill without us. It is our faces that the banks wish to see, our faces that institutions and high representatives wish to see... the effect of interpersonal trust is primordial" (R., born in Mozambique, has been living in Angola since 1988)

At the same time, dealing with the State itself required an acceptance of the various schemes of appropriation of public resources for personal gain, implemented by a wide range of social actors holding administrative and political office. While in proportion to the position of each business partner in the Party/State/Military/Business hierarchy, profit margins "were staggering" and made it possible for each participant to receive their cut.

"As a consequence of the war, we sent containers to Angola full of anything they did not have - basic goods, food, medicines, everything. Our only option was to be on the side of the Government. We sold directly to them, and the Ministries and the Armed Forces. We had - and have - to deal with a market where corruption is a given. They let us in to sell containers to the Government if the minister also got to take something home... I remember that profit margins were staggering. It was enough for everyone to get their cut, and we still made a profit." (M... born in Mozambique, has been living in Angola since 1988)

The privileged connection of Portuguese Ismailis to the Angolan State was a 
business and wealth-enhancing opportunity; however, it also worked as a restriction. A negative and hostile public image of the new "Indian" presence (with no past or historic record in Angola) was rapidly produced, whereby the Indian businessman became responsible for "corruption" and, as a consequence, accused of sabotaging Socialist economic policies.

"During the Socialist regime, several Angolan businessmen and politicians grew rich very quickly, and not always on the up and up. A transitioning society needs scapegoats, and blaming an outsider is easier than blaming someone you know. In certain situations, we paid dearly for this, unfairly so.” (F., born in Mozambique, has been living in Angola since 1987)

The period between 1985 and 1992 is linked to the beginning of the "transition" process from a Socialist economy to what is known as market economy. Gradual reforms were introduced beginning in 1987. In 1990, following the official renunciation of Marxism-Leninism on the part of the MPA, the private sector of domestic (but not international) trade was legalized, a partial price liberalization introduced, and inflation grew uncontrollably (Aguilar, 2006; Vidal, 2007). The 1990s created new business opportunities, while at the same time imposing adaptations on Ismaili business organization. Businesses now had to have Angolan capital and partners, bank accounts in national and foreign currency in local banks, and local addresses in rented or bought commercial infrastructure. At the same time, however, the system allowed these same businessmen to import a wide range of products to their own firms in Angola, which would then sell directly to consumers.

"The Government could no longer buy directly from outside the country, they had to buy locally to strengthen the national economy and foster local investment. So we had to set up firms with Angolan capital, in the local currency and with local bank accounts, buy or rent local premises and offices. So now we were exporting to our own Angolan firms." (Ta., born in 
Mozambique, has been living in Angola since 1992)

The shortages of the post-Socialist State, and the continuation of the civil war until 2002, the legalization of private initiative and its strong dependence on influence and corruption networks created during the Socialist phase allowed Portuguese Ismailis to emerge as a new power, recognized by the State, in the recently established private sector of the Angolan market economy. The "transition" thus offered a second chance to improve the economic prosperity of both Ismailis and the political elites of the new multi-party system, and to strengthen their tacit relations.

"You cannot imagine all that was lacking in a Socialist economy, and the wealth of opportunity that offers to businesspeople like us. I remember that I sent a container, and no matter what its contents, 24 hours after leaving port, it was empty. That's a fabulous level of consumption. There was no competition in that economy, we were the first, and there was actual purchasing power and will to consume.” (Ta)

"To give you an idea of what inflation meant: from 1992 to 1998, the currency was readjusted. In '95, they cut three zeros, that is, 1000 Kuanzas were now worth 1 Kuanza. In'98 they cut 6 zeros, that is, a million Kuanzas was now worth 1 Kuanza. In this economy, the exchange rate was 100 in the morning, 102 at lunchtime and 104 in the afternoon. The following day, we would begin at 106 . Bills were too many to count. It was an extraordinarily hyper-consumerist economy”. (M., born in Mozambique, has been living in Angola since 1990)

In parallel, patronage mechanisms - implemented since the early 1990s as a presidential strategy of political power conservation ${ }^{10}$ - created social niches

\footnotetext{
${ }^{10}$ Such mechanisms were fed by the access of State representatives and President Eduardo dos Santos himself to the revenues of the oil and diamond extraction sectors, through multiple processes of transference of public resources and goods to the political and business elite, as well as through the
} 
characterized by a rapid process of capital accumulation, largely employed in luxury consumption or invested abroad (Hodges, 2011). Such strategies of patronage and their effects on accumulation and consumption offered a third chance to visionary Ismaili businessmen, who seized it. As well as selling luxury goods, several businesses began to offer their mediation services within international banking networks and/or consultancy in placing Angolan capital in foreign banks; at the same time, they selected well-placed individuals within the political hierarchy in order to facilitate business partnerships, in exchange for shares in the capital of these new businesses.

"Back then, our firms were almost $100 \%$ family-based, generation after generation. When decolonization happened and we came to Europe or Canada, our children gradually took their distance from the family business. They went to work in big firms in their area of expertise. Our return to Africa had an interesting effect. Our qualified children were able to come and manage the family business. However, we were also brought up to be pragmatic. In Angola we need to have Angolan non-Ismaili partners. Partnerships are created to succeed.” (Fa., born in Mozambique, has been living in Angola since 1995)

"In Africa, political instability is a given. Our African past taught us as much. We deal with this by not being the exclusive owners of the business, but having partnerships with Angolan citizens and financial institutions. The fact that part of the company is Angolan-owned is a guarantee of security. That's how you do business in Angola." (Gu. born in Mozambique, has been living in Angola since 1996)

In the mid-1990s, Portuguese Ismaili businesses also began to receive -in their "private centres" (the name given to their community centres in a context where Islam is illegal) - a small number of Canadian Ismaili businessmen, born in British East 
Africa, who also had previous trading experience in several regions of East and Central Africa (mainly the Congo, Uganda, Kenya and Tanzania). Information provided by their Portuguese peers encouraged them to begin settling in Angola.

"We have relatives in several countries, and families exchange information; the message that Angola offered a great chance came mainly at the family level. Some Indo-Canadian Ismailis, skilled businessmen, paid us several visits. They wanted to get acquainted with the market, and we gave them reliable information on the market itself and how it worked" (F.)

While internationally it was expected and hoped that the war in Angola would end soon, Canadian Ismaili businessmen explored opportunities locally in a period marked by an increasingly violent conflict, the collapse of agriculture and industry, and difficult circumstances for the circulation of people and goods. Unlike their Portuguese peers, who invested in the institutional and State markets (based in Luanda), they specialized in (mostly food) trading directed at the low-income population, quickly acquiring dominance in the retail market in the Angolan provinces. During the following decades, they also became large businessmen in the industrial sector (iron and steel, plastics, paper, etc.), taking part in and advantage of the economic growth of Angola after the transition phase to a market economy, a process which began slowly between 1997 and 2002, then accelerated rapidly until 2007 (Alves da Rocha, 2011).

"When East African countries became independent, my family moved to Canada. In the 1970s, my father became a small trading businessman - top driving operations. Gradually, he expanded his activities to Tanzania, Kenya, and Uganda. There are many, many opportunities in Angola - and very, very good. This type of information went round my family. First, my eldest brothers came in the 1990s. Six years ago, I myself left Canada. We're a family business, and that's how I came over here. My father is still in Kinshasa.” (K., born in Canada, has been living in Angola since 2006) 
The plurilocalization of their factories and warehouses in various Angolan regions (Lubango, Huíla, Malange, Cabinda, Soio, etc.) has led to the reappearance of traditional strategies of staff recruitment within the trust-based networks of family and community, especially in India (in particular in those cases when the distance between the main office and the local branches is so large that inter-personal trust is crucial).

"The logistics of financial control and investment may be based in Canada, but business is controlled on the ground, by placing family or community members, trusted individuals who live locally and control and manage our businesses, and that's the only way in which we can guarantee the success of our investments" (Fr., born in Kenya, has been living in Angola since 2001)

An optimum relation between wage costs and professional competences, cultural and linguistic affinity - which eases internal communication between the various businesses, located in different regions of Angola and other African countries - and, even more importantly, the (colonial and postcolonial) recognition of the dedication and loyalty of Indian employees to the business projects of their employers continue to justify the recruitment strategy adopted by Indo-Canadian businessmen. ${ }^{11}$

"In Angola, we use the same recruitment strategy as in other African countries. We employ mainly people from India, because of our shared language and culture. Indians are hard-working, they work day and night, they're used to it and are hard workers, they are qualified and efficient, and labour costs are not high". (IC., born in Uganda, has been living in Angola since 1998)

Since 2002, the year in which the Angolan civil war ended, the increase in oil profits and the decrease in military expenditure allowed some public investment on the

\footnotetext{
${ }^{11}$ Recruitment is mediated at both the family and community level. The jamatkhanas in Gujarat and Mumbai frequently help to publicize vacancies, which are then further spread by family and social networks.
} 
part of the Angolan State. However, the divorce between the official and market exchange rate, the ensuing public deficit, difficulties in obtaining foreign loans and the negligible character of the national capital market all contributed to offer a new business opportunity to a number of Ismaili large business owners. Some of their ventures began to inject financial capital, through their shareholding position in BAI (Banco Africano de Investimentos - African Investment Bank), as well as providing support and consultancy services with international banks with the aim of securing foreign loans.

"The credit assistance that we provide our clients is also important. We are in a position to assist them in dealing with national and international banks under advantageous conditions." (N., president of the A. Group)

The gradual control of inflation and currency stabilization, the expansion of the banking and financial system, and political openness to the emergence of new private sectors (e.g. foreign investment in non-oil national economy) have created chances of business consolidation and diversification for Ismaili businessmen of Portuguese and Canadian origin (industry, hospitality, restaurants, technology). However, this required an adaptation of their approach to the Angolan market and an alteration of their relations to Africans.

Following the centuries-old advice of their community leaders, they have been developing political and economic loyalties to the national elites. The main reasons behind their success hinge on a close articulation of their business strategies with contemporary postcolonial logics (including political uncertainty and the changes in power groups). The same framework can also explain the numerous partnerships with Angolan businessmen, as well as the increasing participation in national investment funds. Such associations function as leverage to ambitious economic projects with implications for local development, as well as providing some guarantee against 
potential political upheavals.

"We are very malleable, we have a skill for adaptation that is the reason behind our success. We are not partisan, we are here to develop our businesses, not to become involved in politics. If the development of our businesses requires stronger relations with one group or another, of course we are going to do that, and ever more so. It's also a way not to become hostages of political changes. Should that happen, and result in a decrease or paralysation of business, there will be no nationalisation, because a large part actually already belongs to Angolans.” (Ib., born in Mozambique, has been living in Angola since 1996)

Many Ismaili businessmen already consider Angola as a "medium or long term" project". However, although the family reunification process is in progress ${ }^{12}$, a significant part of their wives does not live permanently in Angola. They often reside in Portugal, Canada, UK or in Dubai ensuring that their children and grandchildren can benefit of a demanding international education, as well as material comforts and better health conditions.

"Over the past few years, one of my jobs has been to set up houses (smiles), one in Portugal, one in Angola, another in Mozambique and yet another in Brazil. Even though I do not manage any part of the business, I am always at my husband's side. However, my main task is preparing my sons. Therefore, I have to create the conditions for them to have the best education". (Fa..., born in Mozambique)

\section{Transnationalism and Integration: Impacts on Identity}

\footnotetext{
${ }^{12}$ Women are active economic agents in Europe and Canada, as well as in some of the African countries where the Ismaili presence has been increasing in the past few years. In Angola, their participation is still limited due to legislation. When she enters the country under family reunification, a wife is bound to her husband's three-year work visa, and cannot hold a job of her own.
} 
Ismailism - even though it means different things to different people - constitutes an identity reference that structures personal, family and community lives. This transnational religious identification gradually became disconnected from a physical space of origin and strengthened by lateral interactions of diasporics with each other. It did not however result in an internally homogeneous diaspora. Processes of diasporic re-categorization oriented by strategies of internal differentiation and hierarchization characterize both the colonial and postcolonial periods.

Strongly promoted by Aga Khan III, the internalization of views and patterns of colonial societies stimulated ambivalent identifications (Trovão 2012) with the colonizers - the Portuguese, in Mozambique, and the British, in the various territories of East Africa - which have functioned as the main drive behind the construction of the Portuguese Ismaili versus East African Ismaili categorical couple.

To the eyes of many interviewees, Kenyan Ismailis were usually represented as the most affluent and "educated", those who had a "more European", "more British lifestyle". "They also were the richest" since "Kenya was the most developed territory from the economic point of view and there was significant European investment." According to the same classification, next came the Ismaili of South Africa - which many considered "a very modern, European country, except for the reprehensible Apartheid system" - and then those of Tanzania and Uganda. Mozambican Ismailis were only placed after these. Portuguese Ismailis, however, favoured a system of values (regarded as "Portuguese") which promoted familiarizing interaction and the affective personalization of inter-ethnic relations - over another (regarded as "British"), which valued the hierarchies of the world system and racial segregation (Trovão 2012).

Both Portuguese and East African Ismailis invested in imperial identities, resignifying them according to their perception of the hierarchy-based and competitive 
organization of the colonial world system ${ }^{13}$, using them as transnational categories oriented towards the production and dissemination of superiority-producing imageries within diaspora. African colonial memories continue to provide a source to invent and justify relative distinctions. They are, however, reworked by post-colonial migratory experiences in Canada, characterized by specific discourses and policies concerning migration and citizenship; or in the UK and Portugal, whose postcolonial traditions of involvement with cultural and religious diversity are markedly different; or, more recently, reconfigured in new diasporic encounters in postcolonial African territories.

"I am a Portuguese, of Ismaili faith. My culture is the Portuguese culture. I lived a long time in Canada, and the difference between me and Canadian Ismailis was always clear. Our flexibility in dealing with people is quite different from those who came from East Africa. Because in Mozambique, we already were quite cosmopolitan (...). As the majority of the Portuguese, we're not very concerned with politics. There are no Ismaili MPs in Portugal. That's another cultural trait. Those who were born in Canada are more participative. There are representatives of our community in Parliament, because the civic and political cultures are different in Canada." (Re., born in Mozambique, has lived in Portugal, Canada and Angola)

Notions of class associated to educational and professional competences, transnational networks and capitals, modernity and westernization became central organizers of the taxonomies of difference and distinction produced by interviewees according to what they perceive as their own identity interests. However, Portuguese and Canadian Ismailis settled in Angola continue to recall the specificity of their experiences of colonialism in the formation of their postcolonial identities. This is

\footnotetext{
${ }^{13}$ It is not our aim herein to provide an historical reflection on Portuguese and British colonialism. Such analysis may be found in Trovão (2012); Horta \& White, 2009; Figueiredo, 2003; Dirks, 2001; Castelo, 1999 or Darwin, 1988, among other scholars.
} 
especially relevant to Portuguese Ismailis, who tend to justify their ability to engage Angolans through face-to-face inter-personal relations - and what this allows in terms of networking, bridging capitals and mutual knowledge - as a legacy of specific traits which they assign to the colonial and postcolonial Portuguese cultural ecology.

"Portuguese Ismailis were always more sociable than those from British East Africa. In Mozambique it was already so, and it was not just a question of business. (...). They can say "in East Africa we had more interaction with whites", and "we also absorbed much of the African culture". But in comparison to what happened in Mozambique, interpersonal relations with Europeans or Africans were very limited. I believe that our ability to deal with different partners and clients - and to do so on a more personal basis makes us very well integrated people in Angola, both economically and culturally" (Ib.)

Transnational religious identifications with Ismailism do not lead then to deterritorialized identities. The involvement of identification with one colonial or postcolonial national context may make it more preeminent than others. And several Portuguese and British East African territories do indeed have this role for a majority of our interviewees. Albeit heterogeneous (even within the same nuclear family), the attribution of the (imaginary, symbolic, affective, etc.) functions of a homeland to one of the Nation-States of migratory settlement forces us to rethink the very distinction between nation and diaspora (Kassam-Remtulla 1999) and therefore to question the notion according to which diasporic populations tend to construct identities which operate outside the nation-state.

"You cannot forget your religious values, nor your national cultures of reference - whether it's the Portuguese, Indian, or Canadian. But you have to adjust to the country where you live, respect its rules, and contribute towards its development; and don't forget to be thankful that the country has 
accepted you and allowed you to thrive there - that's our principle." (Ru., born in Mozambique, has lived in Portugal, Canada and Angola)

\section{Concluding Remarks}

Contemporary Ismaili entrepreneurship in Africa is not an exact replica of the old model, but it does seem to be a reconfiguration of a long-lasting business culture. The table below summarizes a number of common denominators between economic practices and strategies as applied to colonial East Africa and post-colonial Angola.

\begin{tabular}{|c|c|}
\hline Type of business & $\begin{array}{l}\text { Family firms } \\
\text {. Openness outside kin and community networks }\end{array}$ \\
\hline Resources & $\begin{array}{l}\text { Family and community transnationalism } \\
\text { Transnational community cohesion and organization (including } \\
\text { international financial support and economic consultancy frameworks) }\end{array}$ \\
\hline Business organization & $\begin{array}{l}\text { Transnational economic practices } \\
\text { Centrality in the nation-states in which economic actions are socially } \\
\text { embedded }\end{array}$ \\
\hline Business networks & $\begin{array}{l}\text { Recognition of the disadvantages of network closure and self-referential } \\
\text { behaviour } \\
\text {. Potential benefits of participation in competing networks } \\
\text { Importance of face-to-face relations, interpersonal trust and mutual } \\
\text { understanding }\end{array}$ \\
\hline Circulation of knowledge & $\begin{array}{l}\text { Selective secrecy mechanisms (intra- and extra-community) negotiated in } \\
\text { changing circumstances } \\
\text {. Subordination to the Ismaili institutional hierarchy }\end{array}$ \\
\hline Businessmen politics & $\begin{array}{l}\text { Efficient cooperation with the colonial and postcolonial political project } \\
\text { of host societies }\end{array}$ \\
\hline National integration & $\begin{array}{l}\text { Identification and involvement } \\
\text {. Selective cultural incorporation }\end{array}$ \\
\hline
\end{tabular}




\begin{tabular}{|l|l|}
\hline & . Continuation (to a certain degree) of matrimonial endogamy \\
\hline Inter-Ethnic Relations & $\begin{array}{l}\text {. Feelings of being accepted and respected } \\
\text {. Strategies of hostility avoidance }\end{array}$ \\
\hline Social capital & . Both within and beyond ethnic-religious community \\
\hline Identity Impacts & $\begin{array}{l}\text {. Transnational religious identification } \\
\text {. National identifications } \\
\text {. Loyalties to the nation-states of settlement }\end{array}$ \\
\hline
\end{tabular}

The continuing centrality in the (politico-economic, relational, and cultural) logic of the particular nation-state in which Ismaili business activities are embedded, the notion of a disadvantageous network closure, concomitant with the importance of faceto-face contacts, the mutual trust and understanding sustained through personal relations, and the tendency for national loyalty to prevail over religious belonging whenever any potential conflict between the two exists, constitute crucial dimensions of an accumulated tacit knowledge which have significance in order to understand the Ismaili competitive advantage in different African colonial and postcolonial contexts. The way in which business practices mobilised in Africa are differentiated from European or North American management models also reveals the existence of a tacitly non-uniform Ismaili business culture, which values skills of learning, innovation, and adaptation to different historical and socio-cultural environments. As many interviewees mentioned:

"We can control our business at a distance, through numbers and management indexes. In Africa, business depends on interpersonal relations. Those who don't get this, and act as though they were in Europe or North America, end up leaving." (N.)

Much more conceptual and empirical work remains to be carried out with regard to Ismaili Khojas settled all over the world in order to identify specificities, differences and global patterns. Our comparative analysis however suggests a modicum of critical 
distancing from antinomies such as new vs. old transnationalism, coexisting vs. competing processes of integration and transnationalism, unique and territorial identities (imposed upon citizens-subjects by nation-states) vs. hybrid and deterritorialized identities (constructed through diasporic experiences) which frequently feature in current anthropological debates on migrant transnationalism. The memories and experiences we have recorded indicate that border-crossing economic activities and the multiple forms and conditions of their embeddedness can be conceived as an invaluable source of tacit knowledge and competence (functional, behavioural, identitarian) which enable social actors to integrate, while at the same time promoting and renewing their transnational ambitions.

\section{Funding}

The article was supported by the FCT (Portuguese Foundation for Science and Technology) through UID/ANT/04038/2013 - CRIA (Centre for Research in Anthropology).

\section{References}

Aguilar, Renato. 2006. Angola 2005: Surfing the Oil Market. Stockholm: Department of Economics, University of Gothenburg.

Amin, Ash, and Patrick Cohendet. 1999. "Learning and adaptation in decentralised business networks.” Environment and Planning D: Society and Space, 17, 87-104.

Appadurai, Arjun. 1996. Modernity at Large: Cultural Dimensions of Globalization. Minneapolis: University of Minnesota Press.

Bastos, José and Susana T. Bastos. 2010. "What are we talking about when we talk about identities." In Identity Processes and Dynamics in Multiethnic Europe, edited by 
Charles Westin, José Bastos, Janine Dahinden, and Pedro Gois, 313-358. Amsterdam: Amsterdam University Press.

Bastos, Susana T. 2008. "Ambivalence and Phantasm in the Portuguese Colonial Discursive Production”. Lusotopie, XV(1), Indians of Mozambique and Eastern Africa, edited by Joana Pereira Leite, and Nicole Khouri, 77-98. Leyde-Boston: Brill. (also available on line at http://www.lusotopie.sciencespobordeaux.fr).

Bastos, Susana T. 2005a. "Indian Transnationalims in colonial and postcolonial Mozambique." In African Migrations: Historical Perspectives and Contemporary Dynamics, (special issue), Vienna Journal of African Studies, 8, edited by Veronika Bilger, and Albert Kraler, 277-306. Austria: Department of African Studies, University of Vienna.

Bastos, Susana T. 2005b. “«Hierarchical alterity is a mere illusion»: Some reflections on the creative power of women's expressive traditions in Hindu Diaspora". Lusotopie, XII, (1/2), Gendered Social Relationships, edited by Marissa Moorman, and Kahleen Sheldon, 109-124. Leyde-Boston: Brill. (also available on line at http://www.lusotopie.sciencespobordeaux.fr).

Bhabha, Homi. 1994. The Location of Culture. London: Routledge.

Bhagavan, M. R. 1986. Angola's political economy 1975-85. Uppsala: Scandinavian Institute of African Studies.

Boehmer, Elleke, and Frances Gouda. 2009. "Postcolonial Studies in the Context of the Diasporic Netherlands." In Comparing Postcolonial Diasporas, edited by Michelle Keown, David Murphy, and James Procter, 37-55. London/New York: Palgrave/Macmillan.

Castelo, Cláudia. 1999. O Modo Português de Estar no Mundo - O Luso-tropicalismo e a ideologia colonial portuguesa. Porto: Edições Afrontamento.

Clarence-Smith, William G.. 1989. "Indian Business Communities in the Western Indian 
Ocean in the Nineteenth Century." Indian Ocean Review, 2, no 4, 18-21.

Daftary, Farhad. 2000. The Ismailis: Their History and Doctrines. Cambridge: Cambridge University Press.

Dicken, Peter, Philip F. Kelly, Kris Olds, and Henry Wai-Chung Yeung. 2001. "Chains and networks, territories and scales: Towards a relational framework for analysing the global economy." Global Networks, 1(2), 89-112.

Ellis, Stephen, and Yves-André Fauré. 1995. Entreprises et entrepreneurs africains. Paris: Karthala, Orstom.

Figueiredo, António. 2003. "The Empire is dead, long live the EU”. In The Last Empire: Thirty-Years of Portuguese Decolonization, edited by Stewart Lloyd-Jones and, António Costa Pinto, 127-144. Bristol: Intellect Books.

Foner, Nancy. 1997. "What's new about transnationalism? New York immigrants today and at the turn of the century." Diaspora: A Journal of Transnational Studies 6 (3), 33575 .

Granovetter, Mark S. 1985. "Economic action and social structure: The problem of embeddedness". American Journal of Sociology, 91, 481-510.

Gregory, Robert. 1993. South Asians in East Africa. An Economic and Social History 1890-1980. Boulder: Westview Press.

Grillo, Ralph. (2008). The Family in Question: Immigrant and Ethnic Minorities in Multicultural Europe. Amsterdam: Amsterdam University Press.

Guarnizo, Luis Eduardo. 2003. "The economics of transnational living." International Migration Review 37 (3), 666-99.

Hannerz, Ulf. 1996. Transnational Connections. London: Routledge.

Hodges, Tony. 2011. “Fundamentos Económicos do Estado Patrominial.” In Economia 
Política e Desenvolvimento em Angola, edited by Nuno Vidal and, Justino Pinto de Andrade, 87-112. Angola/Portugal: Media XXI.

Hodges, Tony. 2003. Angola: Anatomy of an Oil State. Oxford: James Currey and Bloomington.

Hodges, Tony. 2001. Angola from Stalinism to Petro-Diamond Capitalism. London: James Currey.

Horta, Ana, and Paul White. 2009. "Post-colonial migration and citizenship regimes: a comparison of Portugal and the United Kingdom.” Revista Migrações 4, 33-57.

Inda, Jonathan Xavier, and Renato Rosaldo. 2002. The Anthropology of Globalization, Oxford: Blackwell.

Joppke, Christian, and Ewa Morawska. 2003. Toward Assimilation and Citizenship: Immigrants in Liberal Nation-States. Basingstoke, UK: Palgrave.

Kaiser, Paul J. 1996. Culture, Transnationalism, and Civil Society: Aga Khan Social Service Initiatives in Tanzania. Westport, Connecticut: Praeger Publishers.

Kassam-Remtulla, Aly. 1999. (Dis)placing Khojahs: forging identities, revitalizing Islam, and crafting global Ismailism. Department of Anthropology: Stanford University, Unpublished.

Keown, Michelle, David Murphy, and James Procter. (2009). Comparing Postcolonial Diasporas. London/New York: Palgrave/Macmillan.

Levitt, Peggy. 2001. The Transnational Villagers. Berkeley and Los Angeles: University of California Press.

Levitt, Peggy, and Nina Glick Schiller. 2004. "Conceptualizing simultaneity. A transnational social field perspective on society." International Migration Review 38(3), 1002-39. 
Markovits, Claude. 2000. The Global World of Indian Merchants 1750-1947. Traders of Sind from Bukhara to Panama. Cambridge: Cambridge University Press.

Miller, Daniel. 1995. Worlds apart. Modernity through the prism of the global. London: Routledge.

Morawska, Ewa. 2001. "Immigrants, Transnationalism and Ethnicization: A comparison of This Great Wave and the Last." In Contemporary and Historical Perspectives on Immigrant Political Incorporation, edited by Gary Gerstle, and John Mollenkopf, E. Pluribus Unum?, 175-212. New York: Russell Sage Foundation.

Morris, H. S. 1969. The Indians in Uganda. Chicago: University of Chicago Press.

Penrard, Jean-Claude. 2008. "Disseminated Identities. Musulmans d'origines indopakistanaises en Afrique orientale." Lusotopie, XV(1), Indians of Mozambique and Eastern Africa, edited by Joana Pereira Leite, and Nicole Khouri, 125-140. LeydeBoston: Brill. (also available on line at http://www.lusotopie.sciencespobordeaux.fr).

Penrard, Jean-Claude. 1988. “La présence isma'ilienne en Afrique de l'est. Note sur l'histoire commerciale et l'organisation communautaire." In Marchand et Hommes d'affaires asiatiques dans l'océan Indique et la Mer de Chine, edited by D. Lombard, and, J. Aubin, 13e-20e siècles, 221-36. Paris: Ed. de L'EHESS.

Portes, Alejandro. 1999. "Immigration Theory for a New Century: Some Problems and Opportunities." In The Handbook of International Migration: The American Experience, edited by Charles Hirschman, Philip Kasinitz, and Josh DeWind, 21-33. New York: Russell Sage Foundation.

Portes, Alejandro. 1995. The Economic Sociology of Immigration: Essays on Networks, Ethnicity, and Entrepreneurship. New York: Russell Sage Foundation.

Portes, Alejandro, William Haller and, Luis Eduardo Guarnizo. 2002. "Transnational Entrepreneurs: An alternative Form of Immigrant Economic Adaptation." American 
Sociological Review, 67, 278-98.

Rocha, Alves. 2011. “Crescimento Económico e Desenvolvimento em Angola: Uma Análise para o Período 1997-2009/2010.” In Economia Política e Desenvolvimento em Angola, edited by Nuno Vidal and, Justino Pinto de Andrade, 115-47. Angola/Portugal: Media XXI.

Savadori, Cynthia. 1996. We came in Dhows. Nairobi: Paperchase Kenya Ltd.

Salvadori, Cynthia. 1989. Through open doors, a view of Asian Cultures in Kenya. Nairobi: Kenway Publications.

Smith, Robert Courtney. 2006. Mexican New York: Transnational Lives of New Immigrants. Berkeley CA: University of California Press.

Smith, Robert Courtney. 2003. "Diasporic memberships in historical perspective: Comparative insights from the Mexican and Italian cases." International Migration Review 37 (3), 724-59.

Sumra, Suleman. 1990. The Indigenous Capital and the Asian Question. SIDA SocioEconomic Group Meeting: Dar es Salaam.

Tölölyan, Kachig. 2000. "Elites and institutions in the Armenian diaspora's history." Diaspora: A Journal of Transnational Studies 9 (1), 107-36.

Trovão, Susana. 2010. "Comparing Postcolonial Identity Formations: Legacies of Portuguese and British Colonialisms in East Africa." Social Identities: Journal for the Study of Race, Nation and Culture 18 (3), 261-280.

Vertovec, Steven. 2009. Transnationalism. Oxford: Routledge.

Vidal, Nuno, and Justino Pinto de Andrade. 2011. Economia Política $e$ Desenvolvimento em Angola. Angola/Portugal: Media XXI.

Vidal, Nuno. 2007. "The Angolan Regime and the Move to Multiparty Politics." In 
Angola, the Weight of history, edited by Patrick Chabal, and Nuno Vidal, 124-74. London/New York: Hurst \& Columbia.

Walji, Parveen. 1980. "The Relationship Between Socio-Economic Conditions and Fertility Behavior Among Selected Asian Groups in Nairobi.” PhD diss., University of Nairobi, Kenya.

Yeung, Henry Wai-Chung. 2000. "Organizing the "firm" in industrial geography I: networks, institutions and regional development." Progress in Human Geography 24 (2), 301-15. 